\section{DELIVERING PUBLIC PRIVATE \\ PARTNERSHIPS IN THE EU: \\ THE COMPETITIVE DIALOGUE AS A PROCUREMENT PROCESS}

A new public procurement regime ${ }^{1}$ which governs the award of public contracts in the supplies, works and services sectors, as well as in utilities, has been operational since January 31, 2006. The new public procurement Directives have been seen as an integral part of the Commission's 2000 Work Programme, which pledges to modernize the relevant legislation for the completion of the internal market and at the same time implement the Lisbon European Council's call for economic reform². The new regime reflects on the 1996 European Commission's Green Paper on Public Procurement ${ }^{3}$ and the subsequent 1998 Commission's Communication ${ }^{4}$.

The competitive dialogue is the most publicized change brought about by the new public procurement regime. Its inception is attributed to three reasons: (i) the inability of open or restricted procedures to facilitate the award of complex public contracts, including concessions and public-private partnerships, (ii) the exceptional nature of negotiated procedures without prior advertisement; ${ }^{5}$ and (iii) the restrictive interpretation ${ }^{6}$ of the grounds for using negotiated procedures with prior advertisement.

Article 29 of the public sector Directive establishes the competitive dialogue as an award procedure, alongside open, restricted and negotiated procedures. The competitive dialogue must be used exceptionally in cases of particularly complex contracts, where the use of the open or restricted procedures will not allow the award of the contract, and the use of negotiated procedures cannot be justified. A public contract is considered to be particularly complex where the contracting authorities are not able to define in an objective manner the technical specifications which are required to pursue the project, or they are not able to specify the legal or financial make-up of a project.

The procedure is very complex, as it has three main phases and many options within these phases. Firstly, the advertisement phase according to Article 29(2) obliges contracting authorities to publish a contract notice or a descriptive document outlining their needs and basic specifications of the project. After that phase, and before launching a competitive dialogue for the award of a contract, contracting authorities may, using a technical dialogue, seek or accept advice which may be used in the preparation of the specifications, provided that such advice does not have the effect of precluding competition.

Secondly, a selection phase reduces the candidates to be invited to the competitive dialogue according to the relevant provisions of Articles 44-52 of the public sector Directive ${ }^{7}$. The minimum number of candidates should be three, but it could be lower if there is sufficient evidence of

\section{Articles}

Through the looking glass? Prisoners' children and penal policy 3

From mothering behind bars to parenting beyond barriers? The right to family life and the politics of imprisonment 6 Silent, forgotten and vulnerable: examining the risks for children with a parent in prison

The cost of organized transnational economic crime: a case study from the health sector

Society and Institute News

\section{Articles (cont'd)}

When is case law on the web the "official" published source? Criteria, quandaries, and implications for the US and the UK

The South African Constitution and the transition from apartheid: legislating the reconciliation of rights in a multi-cultural society

competitiveness in the process or the limited number of initial respondents to the contract notice precludes the invitation of at least three candidates.

Thirdly, the competitive dialogue is opened by the commencement of the award phase in accordance with Article 29(3). Contracting authorities must open a dialogue with the candidates selected, the aim of which is to identify the means best suited to satisfying their needs. They may discuss all aspects of the contract with the chosen candidates, ensuring equality of treatment among all tenderers. In particular, they must not provide information in a discriminatory manner which may give some tenderers an advantage over others. Contracting authorities may not reveal to the other participants' solutions proposed or other confidential information communicated by a candidate participating in the dialogue without prior agreement granted from that candidate.

Contracting authorities may provide for the competitive dialogue to take place in successive stages in order to reduce the number of solutions to be discussed with the candidates in accordance with Article 29(4). They may continue the dialogue until they can identify the solution or solutions which are capable of meeting their needs. Having declared that the dialogue is concluded and having informed the participants, contracting authorities must ask them to submit their final tenders on the basis of the solution or solutions presented and specified during the dialogue.

After this phase is over (closure of the competitive dialogue), there are four stages until the contract award. Firstly, contracting authorities must ask all remaining candidates to submit their final tenders (Article 44(4)). Secondly, these tenders need to be finalized prior to their 
evaluation (Article 29(6)). Thirdly, the selection of the winning tenderer must take place in accordance with the criteria stipulated in the contract notice (Article 29(7)), and fourthly the winning tenderer must provide further clarification and his commitment to undertake the project (Article 29(7)).

The tenders must contain all the elements required and considered necessary for the performance of the project. They may be clarified, specified and fine-tuned at the request of the contracting authority. However, any additional information must not involve any changes to the basic features of the tender or the call for tender, nor allow for variations which are likely to distort competition or have a discriminatory effect. In the author's view, there is a great deal of uncertainty over the meaning of clarification, additional provision of tender specification and the extent of fine-tuning, to the degree of compromising the competitiveness and integrity of the procedure.

Contracting authorities must assess the tenders received on the basis of the award criteria laid down in the contract notice or the descriptive document and must choose the most economically advantageous tender in accordance with Article 53. At the request of the contracting authority, the tenderer identified as having submitted the most economically advantageous tender may be asked to clarify aspects of the tender or confirm commitments contained in the tender provided this does not have the effect of modifying substantial aspects of the tender, or of the call for tender, and does not risk distorting competition or discriminating against other candidates.

Overall, the competitive dialogue has addressed many of the features that are important during the award of complex projects and are currently being addressed by negotiated procedures with prior advertisement. In comparison with these procedures, the competitive dialogue allows also for a limited number of participants (three in number), introduces a staged approach to tendering and permits elimination of participants during its internal phases. However it allows significant scope for post-tender negotiations, but it restricts the award of a contract to complete offers.

\section{Christopher H Bovis}

Professor of Law and Jean Monnet Chair in European and Business Law, Lancashire Law School, University of Central Lancashire

\footnotetext{
${ }^{1}$ See Directive 2004/18, OJ L 134, 30.4.2004 on the coordination of procedures for the award of public works contracts, public supply contracts and public service contracts. and Directive 2004/17, OJ L 134, 30.4.2004 coordinating the procurement procedures of entities operating in the water, energy, transport and postal services sectors.

${ }^{2}$ See the proposal from the European Commission OJ C 29 E, 30.1.2001, p 11 and OJ C 203 E, 27.8.2002, p 210; the opinion of the Economic and Social Committee OJ C 193, 10.7.2001, p 7; the opinion of the Committee of the Regions OJ C 144, 16.5.2001, p. 23; the opinion of the European Parliament of 17 January 2002 (OJ C 271 E, 7.11.2002, p 176), Council Common Position of 20 March 2003 (OJ C 147 E, 24.6.2003, p 1) and Position of the European Parliament of 2 July 2003. See also the Legislative Resolution of the European Parliament of 29 January 2004 and Decision of the Council of 2 February 2004.

${ }^{3}$ See the Green Paper on Public Procurement in the European Union: Exploring the way forward, European Commission 1996.

${ }^{4}$ See European Commission, Communication on Public Procurement in the European Union, COM(98) 143.

${ }^{5}$ Negotiated procedures without prior advertisement are exceptionally allowed...when for technical or artistic reasons or reasons connected with the protection of exclusive rights the services could only be procured by a particular provider ... and .... in cases of extreme urgency brought about by events unforeseeable by the contracting authority. In cases C-199/85, Commission v Italy [1987] ECR 1039 and C-3/88, Commission v Italy [1989] ECR 4035, the court rejected the existence of exclusive rights and regarded the abuse of this provision as contrary to the right of establishment and freedom to provide services which are based on the principle of equal treatment and prohibit not only overt discrimination on grounds of nationality, but also all covert forms of discrimination, which, by the application of other criteria of differentiation, lead to the same result. Interestingly, in case 199/85, Commission v Italy, op cit, the court elucidated that exclusive rights might include contractual arrangements such as know-how and intellectual property rights. For urgency reasons brought by unforeseen events to contracting authorities the court established two tests: (i) the need of a justification test based on the proportionality principle, and (ii) the existence of a causal link between the alleged urgency and the unforeseen events (see C-199/85, Commission v Italy, op cit; C-3/88, Commission v Italy, op cit, C-24/91, Commission v Spain, [1994] CMLR 621; C-107/92, Commission v Italy, judgment of 2 August, 1993; C-57/94, Commission v Italy, judgment of 18 May 1995; C-296/92, Commission v Italy, judgment of 12 January 1994).
}

${ }^{6}$ The grounds for using this procedure are confined to: (i) the nature of the works or services or risks attached thereto do not permit overall pricing and (ii) the nature of the services is such that specifications cannot be established with sufficient precision. See Art 7(2)(c) of the Works Directive and Arts 11(2)(b) and 11(2)(c) of the Services Directive. 